\title{
МЕТОДИЧНІ ЗАСАДИ ВИЗНАЧЕННЯ ТА ОЦІНКИ КОНКУРЕНТОСПРОМОЖНОСТІ ПІДПРИЄМСТВ СІЛЬСЬКОГО ЗЕЛЕНОГО ТУРИЗМУ
}

Адамчик 0.0.

аспірант

Херсонський державний аграрний університет (м. Херсон, Україна)

У статті обгрунтовані методичні засади визначення та оцінки конкурентоспроможності підприємств сільського зеленого туризму. Здійснено акцент на тому, що на ії рівень впливає не тільки внутрішнє середовище підприємства та галузі, продуктів і послуг, але чи не найбільший вплив здійснює міжгалузева конкуренція, насамперед, зі сторони сільського господарства. Для оиінки різних аспектів конкурентоспроможності запропоновано сукупність методів: статистико-економічні, розрахунково-конструктивні, нормативні, математичного моделювання, анкетування, опитування. Розроблено алгоритм та виділено змістовні етапи досліджень. Запропоновані принципи оцінки конкурентоспроможності.

Ключові слова: підприємства, сільський зелений туризм, конкурентоспроможність, методичні засади, ціна, якість, моделювання, ресурси, управлінські рішення.

DOI: https://doi.org/10.32845/bsnau.2019.3.26

Постановка проблеми. Підприємства сільського зеленого туризму в економічно розвинених країнах набувають все більшого поширення. Вони розглядаються їх урядами як провідна альтернатива індустріалізованому й автоматизованому високотехнологічному аграрному виробництву з метою забезпечення зайнятості й підвищення добробуту сільського населення, збереження сільського способу життя, сільських поселень і територій. 3 іншої сторони, відпочинок і туризм у природних умовах, серед національних культурно-історичних традицій, побутових звичок і обрядів, автентичного ужитковоприкладного мистецтва набуває все більшої популярності серед широких верств населення.

Сучасні умови функціонування підприємств сільського зеленого туризму в Україні характеризуються високим ступенем невизначеності, сезонною нестабільністю попиту на туристичні послуги, десріцитом інвестицій та фінансових ресурсів, відсутністю маркетингових стратегій орієнтації на клієнта на тлі жорсткої конкуренції у туристичному та суміжних бізнесах. В такому разі вони не можуть обмежитися тільки поточним плануванням й оперативним управлінням своєї діяльності. Виникає необхідність у розробці методичних засад підвищення її ефективності та конкурентоспроможності.

Це спонукає до методичних розробок оптимізації бізнес-процесів; пошуку, формуванню й розвитку конкурентних переваг; боротьби за споживача через розвиток популярних або/та унікальних послуг і продуктів та надання їх власникам туристичного бізнесу на селі. Як правило, вони не мають фахової освіти та керуються власною інтуїцією. Тому такі методичні розробки мають велике практичне значення та повинні бути простими й зрозумілими для користувачів-практиків на селі. Вони допоможуть здійснювати управління діяльністю на основі логічної сукупності простих, але репрезентативних кількісних та якісних індикаторів та показників. Кожному підприємству важливо правильно оцінити конкурентне середовище, у якому воно функціонує, щоб запропонувати ефективні конкурентні стратегії, які б забезпечували конкурентоспроможність та стійкий розвиток на перспективу.

В умовах розвинутого ринку та високого рівня банкрутства суб'єктів господарювання комерційного успіху досягають лише ті з них, які можуть створювати та реалізовувати на належному організаційному рівні довгочасні стратегії конкурентоспроможності. Вибір та застосування цих стратегій неможливий без визначення наявних конкурентних переваг та оцінки конкурентоспроможності підприємства на даному етапі його життєвого циклу, прогнозування й планування на перспективу.

Аналіз останніх досліджень і публікацій. Останніми роками у вітчизняних та зарубіжних джерелах зростає кількість публікацій стосовно напрямів підвищення конкурентоспроможності підприємств. Питання її змісту, складників, чинників фрормування, організаційно- та фінансово-економічних механізмів досягнення й управління розвитком та підвищенням розглянуті у працях Г. Азоєва, М. Долішнього, О. Кузьміна, Й. Петровича, А. Татаркіна, Р. Фатхутдінова, Л. Чайнікової, Н. Чухрай, Л. Шеховцевої та інших.

Методичні аспекти розвитку підприємств сільського зеленого туризму висвітлювалися у працях О. Бейдика, М. Ігнатенка, О. Любіцевої, Л. Мармуль, В. Пеньковського, І. Романюк, у т.ч. конкурентних позицій у працях О. Азарян, Л. Балабанова, І. Бочан, О. Виноградова, С. Гаврилюк, А. Дурович, Ф. Поклонський, В. Полюга, О. Сидорова, Т. Ткаченко, Н. Цопа, Л. Шульгіна. Проте проблеми конкурентоспроможності, конкуренції, конкурентних переваг та ризиків їх функціонування потребують подальших розробок.

Мета статті полягає у визначенні сукупності методів та їх цільового призначення для визначення й оцінки конкурентоспроможності підприємств сільського зеленого туризму, конкурентних переваг та ризиків їх функціонування з метою більшого поширення та розвитку на ринку туристичних послуг, в структурі сільської економіки й забезпеченні зайнятості та підвищення рівня життя сільських жителів та задоволення потреб населення у відпочинку.

Виклад основного матеріалу. Конкурентоспроможність підприємств сільського зеленого туризму розуміється як їх можливості виробляти й реалізувати швидко, дешево, якісно, в достатній кількості, при високому технологічному рівні обслуговування туристичні продукти. 3 цією метою необхідна систематична робота з усього господарського циклу, що призводить до конкурентних переваг у сфері управління, фінансів, маркетингу й т.д. Конкурентоспроможність, отже, $є$ результатом отриманих конкурентних переваг по всьому спектру проблем та напрямів управління діяльністю.

Конкурентоспроможність підприємств сільського зеленого туризму - це також узагальнююча характеристика їх 
стійкості, що зумовлюється ефективністю використання наявного ресурсного потенціалу, здатністю надавати привабливі за ціновими і неціновими характеристиками туристичні послуги й виробляти продукти, можливістю адаптуватися до змін динамічного ринкового середовища [1, с. 176]. Крім економічного, ця категорія несе значне соціальне й екологічне навантаження. Вона сприяє підвищенню рівня облаштування агроосель, організації сільських територій, зайнятості й добробуту сільських жителів, зменшенню навантаження на довкілля та вирішенню екологічних проблем сільської місцевості.

Встановлено, що у сфері сільського зеленого туризму методичні проблеми підприємництва та його оцінки у плані ефективності, конкурентоспроможності, сталого розвитку не вивчалася достатньо систематизовано. Тому часто в їх методиці застосовуються загальні аспекти оцінки фінансово-господарських показників функціонування підприємств. Безумовно, це правильно з методичної точки зору. В той же час слід враховувати, що туризм, тим більше сільський зелений туризм як сфера підприємницької діяльності, має свою специфріку, що спричиняє додаткові вимоги до виявлення, врахування та оцінки всіх аспектів його здійснення.

Підприємництво у сфері сільського зеленого туризму активно розвивається, як уже зазначалося, і в інших країнах світу, для економіки яких він не є новим та недослідженим явищем. 3 метою перейняти методичний та практичний досвід ведення підприємницької діяльності в цій сфері, управління її розвитком та державного регулювання, а також створення сприятливого клімату для подальшого розквіту агроосель в Україні ми порівнюємо показники обсягів туристичної діяльності в різних регіонах нашої країни та в інших державах з використанням статистико-економічного методу, зокрема порівняння [2, с. 48]. Для встановлення взаємозалежності між рівнем туристичних потоків та станом інфраструктури як чинника конкурентоспроможності використано метод статистично-економічних групувань.

У процесі функціонування підприємств сільського зеленого туризму виникає ситуація, за якої велика кількість користувачів спільно споживає одне і те ж благо. Йдеться про використання транспорту, громадського харчування, служб прокату, комунікацій, фінансових послуг тощо. Тому потребує розгляду такий важливий аспект діяльності, як укладання угод на основі принципу користування спільним. Це дозволяє визначити частку й інші кількісні показники підприємств сільського зеленого туризму у виручці, доходах, витратах та ін. Розрахунки здійснюються в умовах конкретних населених пунктів з визначенням можливих обсягів послуг і перспектив розвитку сфери сільського зеленого туризму. У дослідженнях це здійснюється за допомогою розрахунково-конструктивного та нормативного методів. Отримані результати вказують не тільки на рівень конкурентоспроможності підприємств сільського зеленого туризму. Вони також $є$ підставою для надання місцевої, державної підтримки, державно-приватного партнерства, інших інструментів регулювання та управління.

Важливе місце у методиці досліджень конкурентоспроможності надається також ідентифікації та оцінці бізнеспроцесів підприємств та агроосель сільського зеленого туризму. 3 цією метою результативним $є$ використання методу моделювання соціально-економічних процесів. Він тісно пов'язаний із принципом мультиплікації та синергії. Це зумовлено тим, що дохід домогосподарств є одним із видів і джерел формування внутрішніх інвестицій у туристичну діяльність на селі. Відповідно до теорії мультиплікатора, з великою вірогідністю можна припустити, що зі зростанням доходів населення, зокрема сільського, а відтак і інвестицій, можна очікувати на зростання ВВП та надходжень до бюджету в туристичної діяльності на селі [ 3, с. 296].

При цьому до уваги необхідно брати загальний рівень розвитку сільських територій, зниження рівня безробіття на селі, покращання добробуту населення, підвищення рівня освітньо-культурної ссрери, медицини, комунікацій, транспортного обслуговування, громадського харчування і торгівлі, і звичайно, екологічної інфраструктури й інших туристичних дестинацій. Таким чином, метод моделювання з урахуванням принципу мультиплікації дає змогу відобразити взаємозалежності між рівнем зайнятості, доходів сільського населення, організації й розвитку територій і підприємств сільського зеленого туризму та їх конкурентоспроможності. Це дозволяє передбачити проблеми, які потребують вирішення в реформуванні соціально-економічної сфери села з метою попередження чинників невизначеності, ризиків і загроз для підприємств сільського зеленого туризму.

Метод моделювання процесу надання послуг сільського зеленого туризму $є$ ефективним засобом детермінації якісних та кількісних ознак, формалізації функціональних залежностей і тенденцій розвитку. У процесі дослідження створюються моделі, які зображають логічні зв'язки і взаємозалежності у вигляді таблиць, формул та графіків. Кожна 3 цих форм моделей відображає певну характеристику та особливість сільського зеленого туризму як виду підприємницької діяльності та сфери господарювання. За допомогою граффічної моделі показано логіку процесу зміни показників протягом певного періоду та функціональну залежність між ними. Це дозволяє встановити етапи формування конкурентоспроможності, стадії її розвитку, перспектив підвищення.

3 використанням методології синергетичного підходу сільський зелений туризм розглядається як соціально-економічне явище та досліджується як система, що самоорганізується, виникнення і зміна якої ґрунтується на випадкових процесах, особливо в їх кризових, нестабільних станах [4, с. 173]. Враховуючи це, можна зазначити, що сільський зелений туризм виник в умовах зростання рівня безробіття на селі та досягнення ним критичної межі, з одного боку, а з іншого - як реакція жителів міських територій на зростання рівня урбанізації та погіршення стану навколишнього середовища. Проте ці обставини не можна вважати його основоположними конкурентними перевагами. Швидче, це негативні явища, які, тим не менше, призвели до позитивного результату.

Методичні основи дослідження підприємств сільського зеленого туризму включають сукупність інструментів та способів, що дозволяють дати оцінку тому чи іншому явищу. Вони охоплюють інформаційну базу, сукупність критеріїв та показників, основні методи та порядок оцінювання. Оцінювання конкурентоспроможності передбачає оцінку показників фінансово-економічної стійкості підприємств та агроосель як суб'єктів господарювання; їх діяльності за показниками спеціалізації, диверсифікації, розвитку видів туризму; продуктів і послуг за стандартами відповідності й співвідношенням у системі "ціна - якість - собівартість".

Оцінювання ефективності та конкурентоспроможності підприємств сільського зеленого туризму може відбуватися за наступними основними етапами [5, с. 35]: 1. Оцінка ринку, чинників функціонування та вибір підприємств-конкурентів 
для порівняння. 2. Збір необхідної інформації про ринок сільського зеленого туризму та його учасників. 3. Розробка системи оцінних критеріїв, показників та індикаторів. 4. Розрахунок показників функціонування досліджуваних господарств та підприємств сільського зеленого туризму. 5. Побудова порівняльних таблиць, графіків, рисунків як результатів та ілюстрацій оцінювання за найбільш прийнятними методами.

Основними методичними принципами визначення конкурентоспроможності підприємств сільського зеленого туризму є: оцінювання з позицій виробників або споживачів послуг; орієнтації на певний вид та сегмент ринку; забезпечення порівняльності підприємств за типами, формами та видами; дотримання норм національного та міжнародного законодавства; орієнтації на певний тип ринку (внутрішній, зовнішній); попередження подвійного врахування показників; формування сукупності показників, які можна розраховувати на основі статистичних джерел та анкетування або опитування.

Визначення конкурентоспроможності підприємств сільського зеленого туризму означає порівняння різних показників і критеріїв одного підприємства на тлі інших. Тому доречно відзначити відносність даної категорії. Існують різні методи та способи оцінки ефективності функціонування та конкурентоспроможності підприємств сільського зеленого туризму. Серед них виділяються матричні методи, до яких відносяться: матриця "зростання/частка", що розроблена провідною консалтинговою компанією BostonConsaitingCroup (БКГ) [6, с. 17]. Найбільш конкурентоспроможними будуть ті підприємства, що займають значну частку на ринку. Матриця "привабливість галузі/позиція в конкуренції”, що створена компанією GeneralElectric. Найбільш конкурентоспроможними, згідно цієї моделі, будуть ті суб'єкти, які мають більш сильні позиції в конкуренції та працюють у більш привабливих напрямах сільського зеленого туризму.

Наступний важливий методичний підхід до оцінки конкурентоспроможності ґрунтується на використанні системи показників, що відображають ресурсозабезпечення та ресурсокористування. Його концептуальною основою вважається твердження Портера М., що конкурентоспроможність відображає продуктивність використання ресурсів з метою підтримки ринкових позицій на високому рівні [6]. Тому підприємства повинні дбати про найбільш повне та ефективне використання всіх ресурсів, які є зараз та капіталізуються для майбутньої діяльності. Виходячи з цього, конкурентоспроможність можна виміряти за допомогою визначення продуктивності використання ресурсів, яка представляє собою найбільшу віддачу, найбільший результат, що приходиться на одиницю витрачених ресурсів.

Таким чином, в якості оцінки продуктивності доцільно використовувати показник рентабельності виробництва, продукції або/та послуг. Більш повну оцінку дозволяють отримати методи, що базуються на теорії ефективної конкуренції. Згідно з нею, конкурентоспроможними є підприємства, де ефективно організовані виробництво, реалізація товарів або надання послуг та управління фрінансами. Реалізованою за даним принципом $є$ методика консультаційної американської фірми «Даненд Бренд стріт», що містить три групи показників: ефективності виробничо-збутової діяльності; основної діяльності; фінансового стану.

Позитивною стороною застосування даного методу $є$ використання показників, що дозволяють проводити аналіз роботи підприємств сільського зеленого туризму в цілому.
Проте є ряд недоліків, а саме: показники дублюють один одного, не враховуються якість та ціна продукції. Разом з тим застосування непрямих показників (наприклад, відношення чистого прибутку до обсягу продажів або до чистої вартості матеріальних активів чи майна) характеризує ефективність організації систем PR-менеджменту, маркетингових стратегій збуту та просування продукції й надання послуг [7, с. 162].

Другий методичний підхід ґрунтується на систематизованій оцінці показників конкурентоспроможності. Так, Фатхутдинов Р.А. [8, с. 496] пропонує вивчати сильні та слабкі сторони підприємств за допомогою багатокутника конкурентоспроможності, використовуючи вісім основних критеріїв: якість, ціна, фінанси, торгівля, післяпродажне обслуговування, зовнішня політика, підготовка перед продажем, концепція товару, на якому базується діяльність.

У цьому випадку формуються наступні цільові групи показників для контрольної оцінки: 1. Фінанси. 2. Виробничий потенціал. 3. Трудові ресурси. 4. Технології та науково-дослідний потенціал. 5. Організація та управління. 6. Маркетинг. Таким чином, чітке розмежування всіх складових оцінки шляхом виділення основних критеріїв підвищує ефективність аналітичної роботи та є основною перевагою другого методичного підходу. Однак, оцінка функціонування підприємств сільського зеленого туризму в даному випадку є не досить переконливою, оскільки наведені критерії визначаються за допомогою експертних оцінок. Багато в чому така ситуація обумовлена тим, що окремі критерії включають в себе елементи, які не мають кількісних визначень.

Ще одним відомим методичним підходом здійснення оцінки функціонування суб'єктів сільського зеленого туризму $€$ розгляд конкурентоспроможності продукції/послуг та ефективності діяльності в порівнянні з конкурентами. Заключним етапом оцінки ефективності функціонування підприємств сільського зеленого туризму є формування системи бальної оцінки та визначення коефіцієнтів вагомості для його чинників. Для переведення кількісних та якісних показників у відносні величини здійснюється їх порівняння з базовими показниками [9, с. 167]. В якості останніх можуть виступати: нормативні або стандартні показники; середньогалузеві показники; показники підприємств - лідерів ринку; показники підприємств - конкурентів у даній та іншій галузях, регіонах, країнах; минулорічні показники діяльності підприємств сільського зеленого туризму.

Висновки. Методичні засади визначення та оцінки конкурентоспроможності підприємств сільського зеленого туризму передбачають встановлення їх конкурентного положення на ринку та в структурі сільської економіки з врахуванням ризиків і конкурентних переваг; як суб'єктів господарювання; напрямів, спеціалізації та диверсифікації діяльності; продуктів і послуг за стандартами, якістю, собівартістю і ціною. Це передбачає не тільки використання сукупності методів, показників і критеріїв, але й алгоритму та етапів і послідовності оцінкових робіт.

Основними методичними принципами оцінки конкурентоспроможності підприємств сільського зеленого туризму $€$ : оцінювання з позицій виробників або споживачів послуг; орієнтації на певний вид та сегмент ринку; забезпечення порівнянності підприємств за типами, формами та видами; дотримання норм національного та міжнародного законодавства; орієнтації на певний тип ринку (внутрішній, зовнішній); 
попередження подвійного врахування показників; формування сукупності показників, які можна розраховувати на основі статистичних джерел та анкетування або опитування, у тому числі в соціальних мережах в системі Інтернет.

\section{Список використаної літератури:}

1. Бейдик О. О. Рекреаційно-туристські ресурси України: методологія та методика аналізу, термінологія, районування: монограффія. К.: ВПЦ «Київський університет», 2001. 395 с.

2. Мармуль Л., Романюк І. Потенціал конкурентоспроможності підприємницької діяльності у галузі сільського зеленого туризму. Вісник Бердянського університету менеджменту і бізнесу. 2017. № 1 (37). С. 47-50.

3. Тарнавська Н. П. Управління конкурентоспроможністю підприємств: теорія, методологія, практика. Тернопіль: Економічна думка, 2008. 570 с.

4. Любіцева О. О., Панкова Є. В., Стафрійчук В. І. Туристичні ресурси України. К.: Альтерпрес. 2007. 369 с.

5. Ігнатенко М.М., Мармуль Л.О., Сарапіна О.А. Соціально-економічний потенціал сільських територій як основа розвитку підприємств сільського зеленого туризму на засадах інноваційності. Економіка та менеджмент культури. № 2. 2016. С. $32-38$.

6. Портер М. Конкурентная стратегия: методика анализа отраслей и конкурентов. М.: Альпина Бизнес Букс, 2005. 54 с.

7. Мандич O.В., Романюк I.A., Нікітіна O.M. PR-маркетинг як один з інструментів підвищення конкурентоспроможності підприємства. Вісник ХНТУСГ : економічні науки. Вип. 177. 2016. С. 160-165.

8. Фатхутдинов Р.А. Конкурентоспособность организации в условиях кризиса: экономика, маркетинг, менеджмент. Издательско-книготорговый центр “Маркетинг”, Москва, 2002. 892 с.

9. Брич В. Я., Мазур В. С. Управління якістю туристичних послуг в сучасних умовах господарювання. Стратегія економічного розвитку України. 2014. №35. С. 161-172.

Adamchyk 0.0., PhD student, Kherson State Agrarian University (Kherson, Ukraine)

Methodological principles for determination and assessment of competitiveness of rural green tourism enterprises

The article substantiates the methodological principles of determining and assessing the competitiveness of rural green tourism enterprises. Emphasis is placed on the fact that its level is influenced not only by the internal environment of the enterprise and industry, products and services, but perhaps the greatest impact is exerted by intersectoral competition, primarily from agriculture. To assess various aspects of competitiveness, a set of methods is proposed: statistical and economic, computational, normative, mathematical modeling, questionnaires, surveys. An algorithm has been developed and meaningful stages of research have been identified. The principles of competitiveness assessment are offered.

Key words: enterprises, rural green tourism, competitiveness, methodical principles, price, quality, modeling, resources, management decisions.

Дата надходження до редакції: 30.08.2019 р. 